\title{
The forests of Robinson Crusoe Island, Chile: an endemism hotspot in danger
}

\author{
Los bosques de la isla Robinson Crusoe, Chile: hotspot de endemismo en peligro
}

\author{
RodrigoVargas $^{\text {a* }}$, Albert Reif a ${ }^{\text {, María Jose Faúndez }}{ }^{\text {b }}$ \\ * Corresponding author: ${ }^{a}$ University of Freiburg, Institute of Silviculture, Tennenbacher Str. 4, 79085 Freiburg i.Br., Germany, \\ phone: 49(0)761/203-8621, fax: 49 (0) 761/203-3781,rodrigo.vargasgaete@gmail.com \\ ${ }^{\mathrm{b}}$ Universidad de Chile, Facultad de Ciencias, Instituto de Ecología y Biodiversidad (IEB), Santiago, Chile.
}

\begin{abstract}
SUMMARY
Robinson Crusoe Island (RCI), part of Juan Fernández Archipelago, contains more endemic plant species per area than any other island system of the world (1.9 species $/ \mathrm{km}^{2}$ ). Currently, exotic plants are invading all habitats on the island with higher or lower intensity. As two-thirds of the vascular plant species are threatened by extinction, the island has a high conservation priority. Protection of the island's biodiversity is of utmost importance both locally and globally. Using already published information, the main vegetation types defined for RCI were reviewed, considering plant species richness on the International Union for Conservation of Nature conservation categories, amount of invasive exotic plants, and the occurrence of land bird species. The highest number of endemic and endangered plant species was found in the upper and lower montane forest, in which only highly threatened and threatened bird species live. Furthermore, the scientific literature about Juan Fernández Archipelago was reviewed in order to identify missing data needed for effective conservational efforts. So far research in Juan Fernández and RCI has been mainly focused on Botany, usually dealing with taxonomical aspects of singular plant taxa. Detailed studies of ecology, structure, dynamics, processes and services of the forests on RCI are missing in scientific literature. It appears as highly important to fill this knowledge gap in order to be successful in future conservation and restoration initiatives.
\end{abstract}

Key words: conservation, IUCN red list categories, invasive species, Juan Fernández Islands.

\section{RESUMEN}

La isla Robinson Crusoe, parte del Archipiélago Juan Fernández, contiene más especies de plantas endémicas por área que cualquier otro sistema insular en el mundo (1,9 especies $\left./ \mathrm{km}^{2}\right)$. Actualmente los hábitats de la isla son invadidos por plantas exóticas con mayor o menor intensidad. Dos tercios de las especies de plantas vasculares se consideran en peligro de extinción, por lo que la isla representa una prioridad de conservación para la biodiversidad a escala local y global. Utilizando información ya publicada, se revisan los principales tipos de vegetación definidos para la isla Robinson Crusoe, considerando la riqueza de especies en categorías UICN (Unión Internacional para la Conservación de la Naturaleza), la cantidad de plantas exóticas invasivas y la ocurrencia de especies de aves terrestres. La mayor proporción y número de especies de plantas endémicas se ubicaron en el bosque montano alto y bajo de la isla, donde habitan en mayor abundancia especies de aves endémicas altamente amenazadas. Adicionalmente, para percibir necesidades de información para la conservación, se analizaron los principales temas de publicaciones científicas desarrolladas sobre el archipiélago Juan Fernández. Hasta hoy la investigación en Juan Fernández se ha centrado en botánica, normalmente, en temas relacionados con aspectos taxonómicos de especies de plantas singulares. Estudios en ecología, estructura, dinámica y procesos de los bosques de la isla Robinson Crusoe han sido escasamente tratados en publicaciones científicas. Es urgente abarcar, comprender y vincular estos temas hacia iniciativas de conservación y restauración aplicada.

Palabras clave: conservación, categorías UICN, lista roja, especies invasivas, archipiélago Juan Fernández.

\section{INTRODUCTION}

Plants and animals that somehow have arrived on islands adapt and may evolve in those isolated ecosystems in a unique way. Adaptive radiation following migration helps species to occupy different environmental or ecological niches. Therefore, the high number of endemic species on islands can, at least partly, be explained by speciation through mutation and selection (Cronk 1997). The evolution of species in isolation without much intraspecific competition results in a major susceptibility of island biota to invasive species and human impact (Loope and Mueller Dombois 1989).

Although islands cover only about $2 \%$ of the terrestrial surface, their contribution to global biodiversity is substantial. Around $14 \%$ of all mammals and more than one quarter of bird species occur on island ecosystems (Myers et al. 2000). Similar patterns can be observed for vascular plant taxa (Hahn et al. 2005). Because of their small land areas and high levels of endemism, islands are likely to offer high returns for species conservation efforts and therefore warrant a high priority in global biodiversity 
conservation (Kier et al. 2009). Nine of the world's 25 biodiversity hotspots for conservation priorities are mostly or completely made up of islands (Myers et al. 2000).

Juan Fernández Archipelago Biosphere Reserve (Chile, South east Pacific at $33^{\circ} \mathrm{S}$ ) is one of those biodiversity hotspots. Composed by three oceanic islands, the archipelago accounts for less than $100 \mathrm{~km}^{2}$ of land mass, which represents about $0.01 \%$ of Chile's territory. However, the islands concentrate more than $5 \%$ of Chile's endemic vascular plants (Marticorena 1990). One family, twelve genera and 135 species of plants are endemic to Juan Fernández Islands (Danton and Perrier 2006). Particularly Robinson Crusoe Island, the only permanently inhabited island of the archipelago, presents more endemic plants per area than any other island of the world (93 species in 4,794 ha i.e., 1.9 endemic species $/ \mathrm{km}^{2}$; Stuessy 1992). In addition, almost one third of the Chilean endemic avifauna can be found on Juan Fernández archipelago (Rau 2006).

The extinction of some plant species illustrates the conservation issues that the flora of Juan Fernández is faced with. Santalum fernandezianum Phil. (Santalaceae), a tree of precious wood, became extinct in 1913, and Asteraceae, Robinsonia berteroi (DC.) Sanders, Stuessy et Martic in 2004. The flora of Robinson Crusoe Island is especially endangered. Only about $20 \%$ of the island's vegetation remains fairly undisturbed (Greimler et al. 2002a). At present, exotic animals and weeds invade all habitats on this island (Danton and Perrier 2006). The future of native flora and avifauna appears to be uncertain if conservation and restoration activities are not successful in the middle and long term (Dirnbörk et al. 2003, Hahn et al. 2005).

To implement restoration initiatives it is advisable to know the habitats of the most endangered species as well as their biology, ecology and dynamics. Thorough research of this kind seems to be lacking even though plants have been studied and collected on the islands since 1823 (Skottsberg 1956).

In this literature review the objectives are: i) to identify in which vegetation types of Robinson Crusoe Island the most endangered vascular plant and threatened land bird species are found, and ii) to analyse on which aspects of nature and vegetation of the Juan Fernández Islands past research has been focused on. The idea is to pinpoint areas of conservation interest highlighting information gaps for conservation.

\section{ABOUT THE NATURAL HISTORY OF JUAN FERNÁNDEZ ISLANDS}

Study area. Juan Fernández Archipelago National Park and Biosphere Reserve comprises three islands located between 680 and $860 \mathrm{~km}$ west of central Chile. Robinson Crusoe Island is the closest one to the continent $\left(47.9 \mathrm{~km}^{2}\right.$, $\left.33^{\circ} 37^{\prime} \mathrm{S}, 78^{\circ} 51^{\prime} \mathrm{W}\right)$. San Juan Bautista, on Robinson Crusoe Island, is the only settlement on the archipelago housing $c a$. 700 permanent residents. The climate is Medi- terranean with an oceanic influence presenting an average temperature of $15.2^{\circ} \mathrm{C}$ and an annual precipitation of $957 \mathrm{~mm}$ (Hajek and Espinosa 1987).

The Juan Fernández Islands belong to the few places in the Pacific that remained untouched by humans until their discovery by European sailors in the late XVI century (e.g. Galápagos Islands, Revillagigedo Archipelago, Bonin Islands). Polynesians did not reach further than Easter Island and the Native Americans stayed on and near the South American mainland (Hahn et al. 2009). Juan Fernández is characterized by its biogeographical isolation. The lack of neighbouring islands within $500 \mathrm{~km}$, the long distance to the mainland, the cool Humboldt Current flowing northwards parallel to the South American continent, and the mainly southerly to westerly winds form an environment that sustains a discrete floristic region, neither entirely belonging to the Neotropical nor to the Subantarctic flora (Hahn et al. 2009).

Robinson Crusoe Island vegetation types. Vegetation on Robinson Crusoe Island comprises ca. 3,750 ha of surface, composed mainly of grasslands, shrublands and forest formations (Greimler et al. 2002a). Vegetation is related to the Valdivian coastal formations of southern Chile and has some common characteristics with the subtropical islands communities of the New Zealand region as well as the Hawaiian Metrosideros-forest (Skottsberg 1953, MuellerDombois and Fosberg 1998). There are eight main vegetation types on Robinson Crusoe Island that comprise ca. 3,133 ha obtained by excluding minor scattered vegetation units (see Greimler et al. 2002b):

i) Endemic upper montane forest (753.5 ha extension, 350$650 \mathrm{~m}$ a.s.l.). Is located on steep slopes, dominated by the endemic tree species: Myrceugenia fernandeziana (Hook. et Arn.) Johow (Myrtaceae) and Drimys confertifolia Phil. (Winteraceae). The fern species: Dicksonia berteroana (Colla) Hook. (Dicksoniaceae) and the treelet Coprosma oliveri Fosberg (Rubiaceae) are frequent on the understorey. The palm tree Juania australis (Mart.) Drude ex Hook. f. (Arecaceae), the tall forb Gunnera peltata Phil. (Guneraceae) and species of the Asteraceae genus Robinsonia are common in this vegetation type.

ii) Endemic lower montane forest (441.9 ha of extension, 220-410 m a.s.l.). It comprises woodlands dominated by M. fernandeziana. Fagara mayu (Bertero ex Colla) Engl. (Rutaceae) and D. confertifolia. The endemic trees Rhaphithamnus venustus (Phil.) B. L. Rob. (Verbenaceae), Coprosma pyrifolia (Hook. et Am.) Skottsb. (Rubiaceae) and Boehmeria excelsa (Bertero ex Steud.) Wedd. (Urticaceae) occur with less abundance in this vegetation type (Vargas et al. 2010).

iii) Ugni molinae Turcz. (Myrtaceae) shrubland (232.2 ha of extension, 200-600 m a.s.l.). It is a hard leaved shrub community occurring along the ridges and upper slopes of Robinson Crusoe Island, mainly on the NE side. Ugni molinae, introduced from the mainland, dominates this 
formation with some endemics like Ugni selkirkii (Hook. et Am.) O. Berg (Myrtaceae) or Blechnum cycadifolium (Colla) Sturm (Blechnaceae).

iv) Rubus-Aristotelia shrubland (718.3 ha extension, 140$420 \mathrm{~m}$ a.s.l.). This vegetation type is formed by dense pure thickets of the exotics: Rubus ulmifolius Schott (Rosaceae) and Aristotelia chilensis (Molina) Stunz (Eleocarpaceae). It is located mainly near the lower border of montane forests. The previous endemic montane forests, today invaded by R.ulmifolius and A. chilensis, were included in this vegetation type (Gremler et al. 2002b)

v) Acaena argentea Ruíz et Pav. (Rosaceae) vegetation (439.3 ha, $<400 \mathrm{~m} \mathrm{s.l).} \mathrm{It} \mathrm{is} \mathrm{located} \mathrm{especially} \mathrm{on} \mathrm{the} \mathrm{west-}$ ern part of the island, where the exotic A. argentea colonizes eroded areas. Few introduced grasses and herbs are scattered within this matrix; native species are infrequent. vi) Grasslands (248.7 ha extension, 20-450 m a.s.1.). Native grasslands and grasslands with $A$. argentea associations defined by Greimler et al. (2002b) were bundled together in this vegetation type. The natives Poaceae Nassella laevissima (Phil.) Barkworth and Piptochaetium bicolour (Vahl) E. Desv. are common in this unit.

vii) Weed vegetation (175.6 ha, $15-450 \mathrm{~m}$ a.s.l). This vegetation type corresponds to grasslands occurring on the eastern part of Robinson Crusoe Island. It is dominated by European species such as Rumex acetocella L. (Polygonaceae), Vulpia sp. and Avena barbata Pott ex Link (Poaceae).

viii) Exotic plantations (123.9 ha, 110-170 m a.s.l.). These are located in the surroundings of San Juan Bautista town to provide wood for the local community. They are composed by pure and mixed stands of Eucalyptus globulus Labill (Myrtaceae), Cupressus goveniana Gordon (Cupressaceae) and Pinus radiata D. Don (Pinaceae).

Land bird species. From a biogeographic point of view, the birds on Robinson Crusoe Island ( $\mathrm{N}=41$ species) correspond to the temperate, subantartic, and neotropical taxa. Robinson Crusoe Island shares species with Chilean mainland, Easter Island, Desventuradas, Chiloé and Mocha islands (19 \% similarity) (Hahn et al. 2009). Most birds are non-breeding visitors (28 species) that mainly rely on marine environments (22). Some regular breeders (11) are endemic to the Archipelago (46\%).

Most breeding birds on Robinson Crusoe Island are land bird species $(\mathrm{N}=8)$ that range from widespread taxa such as Columba livia f. domestica, Passer domesticus and Turdus falcklandii ssp. magellanicus to more local species like Asio flammeus suinda, Sephanoides sephaniodes, Falco sparverius ssp. fernandensis, Anairetes fernandezianus and Sephanoides fernandensis (Hahn et al. 2005, 2006, 2009).

Natural history research on Juan Fernandez archipelago and Robinson Crusoe Island. The most comprehensive study about the natural resources of Juan Fernandez was compiled between 1920 and 1953 by Carl Skottsberg. The Swedish scientist co-authored "The natural history of Juan Fernández and Easter Island”, referring to the algae, fungi and vegetation communities of the islands (Skottsberg 1953). In 1896, Johow published a review of the flora of Juan Fernández archipelago (Johow 1896), a work that has never been updated. Stuessy and collaborators helped to estimate the age of the islands (ca. four million years for Robinson Crusoe Island; Stuessy et al. 1984), and Castilla, together with several scientists (Castilla 1987) compiled a broad inventory for the Archipelago (and other oceanic islands) with respect to their geology, meteorology, marine biology, fishery, ornithology, entomology, and vegetation.

More specialized papers are dealing with genetic and breeding aspects of noteworthy plant species (Bernardello et al. 1999, 2001, Anderson et al. 2001). A map defining the vegetation types of Robinson Crusoe Island was produced by Greimler et al. (2002b). Danton and Perrier (2006) developed a complete catalogue of the vascular flora of the archipelago. Hahn et al. (2005, 2006, 2009) characterized the bird communities on the islands.

\section{CONDUCTED ANALYSIS}

Endangered plant species in the main vegetation types. All analyses and results presented in this review are based on the main vegetation types of Robinson Crusoe Island (Greimler et al. 2002a; 2002b) and the catalogue of the island flora detailed by Danton and Perrier (2006).

After sampling 106 vegetation plots (releves) all over Robinson Crusoe Island using the Braun- Blanquet cover abundance scale, Greimler et al. (2002b), identified 15 vegetation types on the island. The main vegetation types consider the eight largest plant communities (sampled through 97 plots, Greimler et al. 2002a). The total richness of vascular plant species present in each releve (97) was estimated. Endemic, native, and exotic plant species were counted, and the richness of "endangered" and "invasive exotic" taxa was evaluated. For the main vegetation types the total number of species in each category was obtained for each plot, and then averaged.

Native and endemic species were classified using the criteria of the endangered species red list of the International Union for Conservation of Nature (IUCN) provided by Danton and Perrier (2006). These categories were simplified to improve interpretation: a) "critically endangered" and "endangered" were regarded as those species that present an extremely high or a high risk of extinction in the wild; b) "vulnerable" were considered those species that are menaced in the wild, and c) "least concern" was attributed to species that are at low risk of endangerment.

The grade of invasiveness of exotic species was assessed using two categories sensu Danton and Perrier (2006): a) "dangerous invasive" i.e. exotic species already naturalized in the wild which endanger the survival of native species and b) "species with naturalization risks", i.e. 
exotic species that present a certain risk of naturalization in the wild. Some exotics could not be classified because of c) "insufficient information".

To stabilize the sample effort among vegetation types, we used 999 non parametric bootstrap pseudo-replicates, re-sampling the original data sets (with replacement) to calculate the confidence intervals $(95 \%)$ for the mean species richness on each defined category. This was especially useful for the analysis of vegetation types with an insufficient number of plots. Analyses were done using the $\mathrm{R}$ project statistical program (R development Core Team 2010, Canty 2002).

Land birds habitat types and conservation status. We considered land bird species given they directly interact in the vegetation communities and some taxa present serious conservation problems (Hagen et al. 2005). Moreover there is good information available (Hahn et al. 2005, 2006, 2009). For all land bird species analyses we used the avifauna distribution lists detailed by Hahn et al. (2005, 2006, 2009).The authors sampled plots and line transects for visual and acoustic recognition of birds based on vegetation, estimating species abundances (Hahn et al. 2005). Six land bird habitat types were identified on Robinson Crusoe Island (Hahn et al. 2005). The land bird habitat types differ slightly from the main vegetation types (Greimler et al. 2002b). Upper and lower montane forests are bundled into one bird habitat type. Also, grasslands, A. argentea vegetation, and weeds assemblages are grouped in "grasslands and weed vegetation" (Hahn et al. 2005, 2009). The "settlement area" considered by Hahn et al. (2005) was excluded because this presented no floristic records (Greimler et al. 2002b), thus only five bird habitat types were considered in the analysis.

The number of breeding land bird species in each main vegetation type was evaluated taking into account the vegetal formations employed as habitats by land bird species. Abundances categories for each land bird species were defined using the population estimations of Hahn et al. (2006).

To consider the conservation status of land bird species, we took the geographical classification of Hahn et al. (2009). Not only ecological factors (e.g. reproduction, competition, predation, etc.) but also geographical features can provide information about the conservation value and need for a given bird taxon (Hahn et al. 2009, Walter 2004). Each bird species was independently ranked in regard to its conservation status based on six geographical parameters: history, area, dispersion, vagility, isolation and location (see eigenplace index: Walter 2004, Hahn et al. 2009).

To simplify the conservation status interpretation for land bird species three geographical conservation classes were defined: a) "highly threatened", i.e. bird species with restricted habitat and low abundance, b) "threatened", i.e. bird species geographically restricted but with higher vagility and abundance, and c) "not threatened", i.e. bird species with a wide distribution and larger dispersion potential and population.

Research about Juan Fernandez Islands. Based on Thomson-Reuters Web of Science (Web of Science 2010) we compiled the different scientific subjects studied about Juan Fernandez and Robinson Crusoe Island to identify the most studied topics related to the vegetation of Juan Fernández Islands. Although there is a lot of information apart from this citation system scattered among books, undergraduate theses, internal reports and local studies (i.e. grey literature); the data provided by this platform is a proxy for quality qualitative scientific information available for the islands. Even if some studies are missing, the Web of Science provides an excellent account of the current literature (de Bello et al. 2010).

We employed the specific keywords: "Juan Fernandez Islands", "Juan Fernandez archipelago", and "Robinson Crusoe Island" searching for the title for each scientific paper. We compiled the results by attributing the main thematic subject to each paper based on standard definitions (Web of Science 2010). We considered six broad thematic disciplines: botany, conservation, marine biology, zoology, medicine, and "other sciences". The latter included papers dealing with geology, climatology, architecture, and literature.

Botanical studies were subdivided in subjects dealing with taxonomy, morphology, physiology, vegetation sciences, forestry, and ecology (Sitte et al. 2002). Conservation papers included studies on scientific divulgation, applied ecology research, invasive exotic species, and endangered species propagation.

\section{RESULTS}

Endemic and endangered plant species in the vegetation types. The associations accommodating most endemic species were the upper and lower montane forest, followed by the Ugni molinae shrubland (figure 1A). The upper and lower montane forests contained in average more than 75 $\%$ and $65 \%$ of endemic species respectively. The other vegetation types had lower total numbers and proportions of endemics $(0-40 \%)$. The average number of exotic species was noticeably higher in the weed vegetation, grasslands, and exotic tree plantations (figure 1A).

Except for the exotic plantations, all vegetation types contained species that were considered as endangered or vulnerable. The montane forests (upper and lower) and the Ugni molinae shrubland were the only associations that held a considerable number of endangered and critically endangered plant species. Around one quarter of native and endemic species in these associations were classified as critical endangered and endangered, or vulnerable (figure 1B).

Most exotic species found in the main vegetation types 


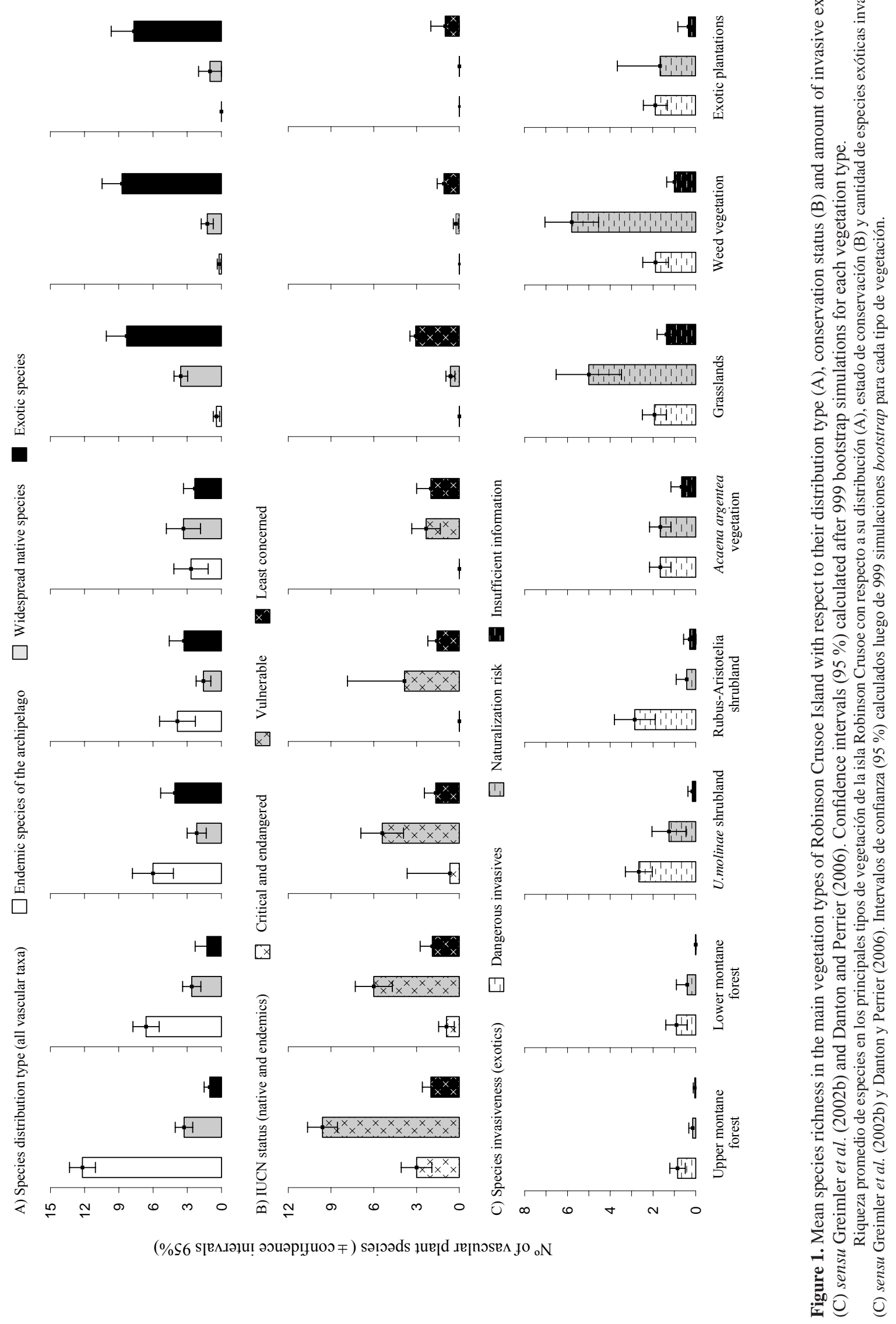


of Robinson Crusoe Island were classified as with naturalization risk or as dangerous invasive. Despite a lower average frequency of exotics, the proportion of dangerous alien species was the highest in the Rubus-Aristotelia shrubland and in the upper montane forest (ca. > $70 \%$ ). Species on the Weed and Grassland vegetation types were mostly exotics classified as "with naturalization risks" (figure 1C).

Land bird habitat types and conservation status. The resident land bird species on Robinson Crusoe Island (8) are distributed homogenously throughout the different habitats, usually living in more than one vegetation type. Bird species tend to prefer the habitat provided by exotic plantations, montane forests, and the Rubus-Aristotelia shrubland. Exotic bird species (2) accumulate around $10 \%$ of the total bird population on Robinson Crusoe Island. Native land bird species (3) accumulate ca. 60\% being present in all habitat types. Endemics birds (3) concentrate $c a$.
$30 \%$ of the total land bird population (figure 2).

Endemic and native birds presented their highest abundance in the upper and lower montane forests (> 2400 individuals). Although endemic bird species were present in exotic vegetation types such as the Rubus-Aristotelia shrubland and forest plantations, their abundance on them was very low ( $<800$ individuals).

Focus of studies on Juan Fernández archipelago and Robinson Crusoe Island. The amount of information is relatively large considering the small area of the islands. A total of 108 articles covering diverse scientific topics referring to the Juan Fernández Islands were found (figure 3). Most of the studies were about botany (51 papers) and marine biology (14), but research papers in geology, climatology, architecture and literature have also been published (included in other sciences, figure 3).

Within the fields of botany and conservation, most pa-

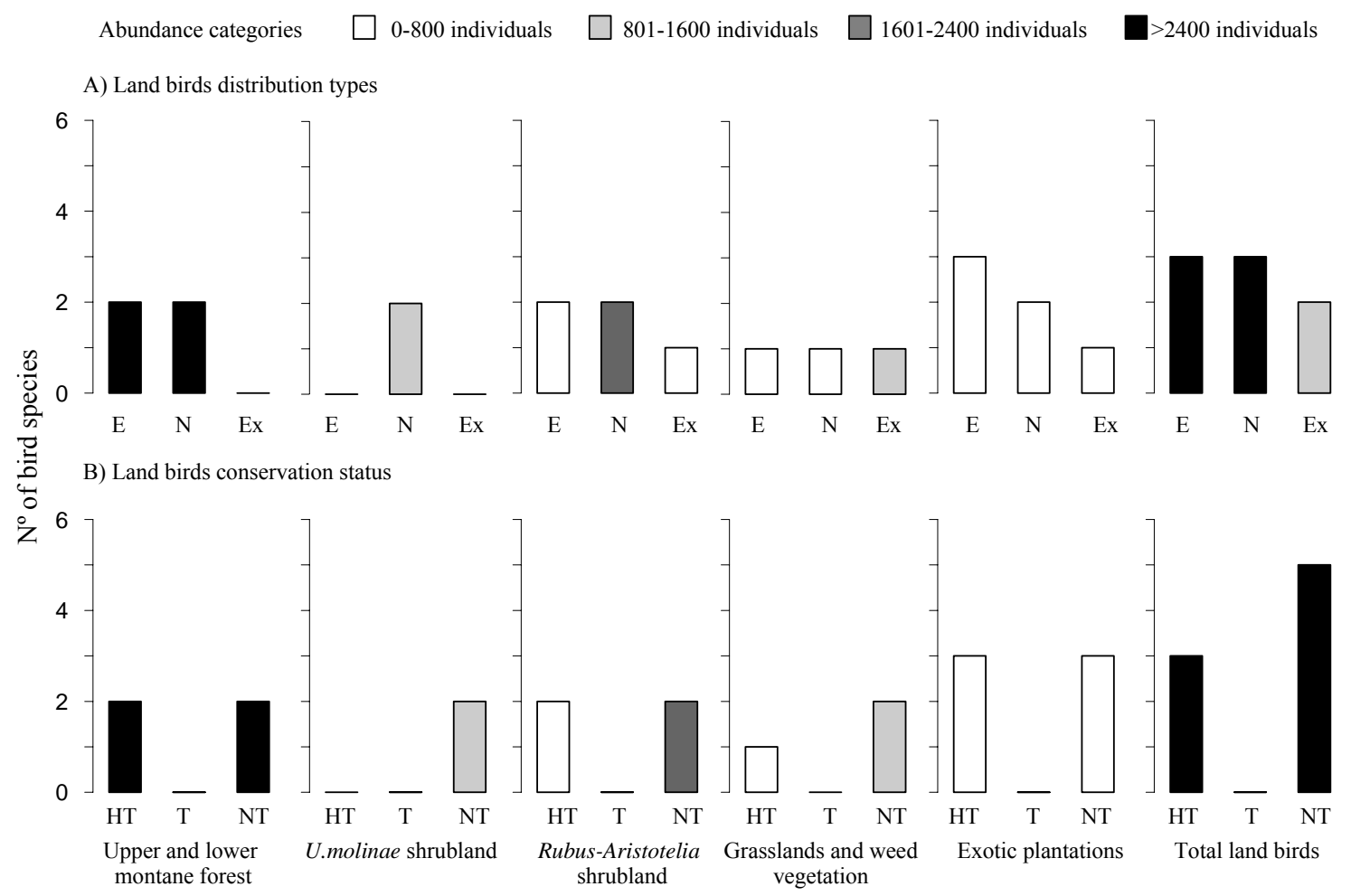

Figure 2. Number of resident land bird species in the most important vegetation habitat types of Robinson Crusoe Island. First line considers bird distribution types: $\mathrm{E}=$ endemic species, $\mathrm{N}=$ Native species (widely dispersed), Ex = exotic species. Second line includes the geographical conservation status: HT = highly threatened, $\mathrm{T}=$ threatened, $\mathrm{N}=$ non threatened. The colours of the bars represent abundance classes on each category. Data sensu Hahn et al. (2005, 2006, 2009).

Número de aves terrestres residentes en diferentes tipos de hábitat de la isla Robinson Crusoe. La primera fila considera el tipo de distribución de las aves: $\mathrm{E}=$ especie endémica, $\mathrm{N}$ = especie nativa (ampliamente distribuída), Ex = especie exótica. La segunda fila incluye el estado de conservación geográfico: $\mathrm{HT}=$ altamente amenazada, $\mathrm{T}=$ amenazada, $\mathrm{N}=$ no amenazada. Los colores de las barras representan clases de abundancia en cada categoría. Datos sensu Hahn et al. (2005, 2006, 2009). 


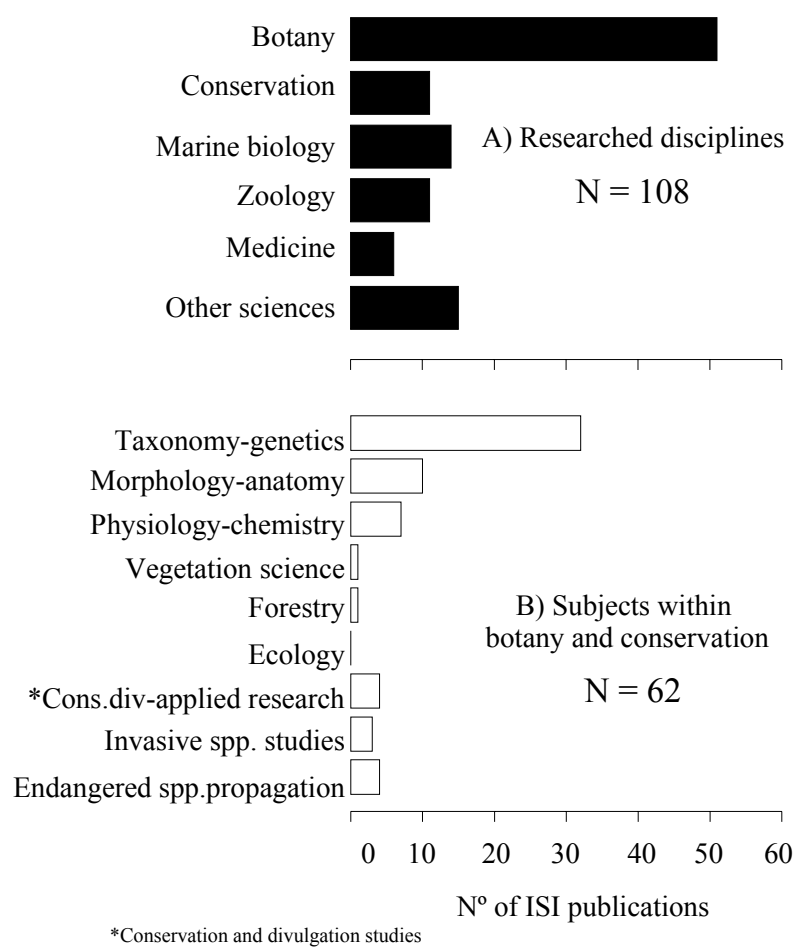

Figure 3. Research papers on scientific subjects on Juan Fernández Archipelago (Web of Science 2010).

Trabajos de investigación en temas científicos acerca del archipiélago Juan Fernández (Web of Science 2010).

pers deal with taxonomical and genetic aspects of fauna and flora (32). Specific topics that could present some interest, like: ecology and forestry have been scarcely treated in ISI journals ${ }^{1}$, and there is only one specific paper referring to vegetation sciences. Conservation research has been focused on scientific divulgation, endangered species propagation and invasive species studies.

\section{DISCUSSION}

Forest: conservation hotspot. The most critical areas for plant conservation on Robinson Crusoe Island are the montane forest formations. They concentrated the highest number and proportion of endemic and endangered plant species. In addition, they constituted the most important habitat type for two of the three endemic land bird species of Robinson Crusoe, including the highly threatened hummingbird Sephanoides fernandensis and the Juan Fernández Tit tyrant Anaerites fernandezianus (Hahn et al. 2005). Almost all of the exotic plants occurring on these vegetation types are dangerously invasive which might affect the survival of native vascular species by competition or direct suppression (Danton and Perrier 2006), disturbing

\footnotetext{
${ }^{1}$ Thomson Reuters ISI (Web of Science 2010).
}

also the nesting habitat of endemic bird species (Hagen et al. 2005).

Around $70 \%$ of plant species of the upper and lower montane forest were endemic. The proportion of endemic plants was considerably higher than that of other similar ecosystems such as the coastal Valdivian forest in Chile (ca. $50 \%$ of endemism) or the woodlands of Polynesian and Micronesian regions (ca. $57 \%$ ) which are both considered priority areas for biodiversity conservation (Biodiversity Hotspots 2010).

In four of the eight main vegetation types found on Robinson Crusoe Island more than half of native species were ranked as vulnerable, endangered or critically endangered. This agrees with Ricci (2006) who assesses the majority of the native flora of the archipelago as in danger of extinction. A similar condition can be found for the vegetation of Hawaii and Canary Islands where $40 \%$ and $20 \%$ of its endemic taxa (respectively) are classified as endangered (Loope and Mueller-Dombois 1989). Consistently, one third of all known endangered plants occur on oceanic islands (Francisco-Ortega et al. 2000).

On Robinson Crusoe Island, bird species seem to prefer well structured vegetation, higher than $3 \mathrm{~m}$ meters without much preference for plantations or montane forests. Most bird species on the island occur in exotic plantations (six from eight) but generally in low abundance $(<800$ individuals). Forest plantations are located near San Juan Bautista town. This area, in a small spot, presents a mosaic of gardens, thickets and exotic plants of high feeding potential for birds (Hahn et al. 2005). This is normal in central Chile, where pine plantations on the surroundings of coastal fragmented forests hold most of native bird species (Tomasevic and Estades 2007).

Among vegetation types, the richness of land bird species did not differed greatly. However there were divergences considering land bird species population: endemic and threatened bird species were more copious in the montane forest. Native and endemic bird populations depend on the conservation of the original vegetation of Robinson Crusoe Island (Hahn et al. 2005, Hagen et al. 2005). The native land bird species (S. sephanoides and T. falcklandii) were the only widespread distributed within all the Robinson Crusoe Island habitat types presenting the highest populations. Especially the abundance of $T$. falcklandii is currently considered as a huge conservation problem given its interaction on the dispersion of the most invasive exotic weeds (R. ulmifolius, A. chilensis and U. molinae). This might have helped the success and speed of a plant invasion process in Robinson Crusoe Island, with deplorable effects on the native biodiversity of the island ${ }^{2}$.

Conservation status and information needs. The loss of biodiversity is a problem that occurs on a local or regional scale but presents a negative global impact that may affect important ecosystem processes (Wardle and Zackris-

\footnotetext{
${ }^{2}$ C. Smith-Ramírez. Personal communication.
} 
son 2005). It is thought that biodiversity loss may have already surpassed the boundaries of safe operating space for human sustainability, making urgent to advocate for its protection and restoration (Rockström et al. 2009).

Juan Fernández Archipelago has been considered of high priority for Chile's biodiversity conservation due to its conservation risk, its limited area and high levels of endemism (Biodiversa 2009). Despite the importance of the archipelago, there are only few studies referring to ecological or structural characters of the island's forests (Vargas et al. 2010). Although specific studies dealing with the woodlands of the archipelago (Danton 2006) even assigned a name for Juan Fernández forest formations ("Myrtisilva (-ae)") there is no information about the patterns, heterogeneity, functions or dynamics of these ecosystems. This knowledge, however, might be necessary as reference state for active conservation (Hobbs 1996).

Conservation literature about Juan Fernández Archipelago is dominated by case studies of noteworthy species. Different reasons, like the large distance to mainland, and the interest mainly related with conservation, far away from economical direct profitable activities, might explain the low scientific attention towards these forests (Anderson et al. 2001, Bernardello et al. 2001), that lack of studies with integrated ecological research scope.

Similar forest relicts in continental Chile such as Fray Jorge National Park (ca. 10,000 ha) are covered in less scientific publications, but $c a .30 \%$ of the papers refer to the ecological forest characteristics (Web of science 2010, Gutiérrez et al. 2008). Similar temperate forests of southern central Chile, that are less interesting in terms of endemism and endangered species, have been widely studied (Veblen et al. 1981, Donoso 1993, Armesto et al. 1998). Forests on other oceanic islands such as Canary (Fernandez-Palacios and Arévalo 1998), Azores (Elias and Dias 2009), Hawaii (Mueller-Dombois 1987) and Bonin (Kawakami and Okochi 2010) have also attracted more scientific attention.

The forests of Robinson Crusoe Island are the only woodlands in Chile (and possibly in the world ${ }^{3}$ ) that are formed exclusively by endemic tree species. If appropriate actions to save the forests are not taken soon, they will be lost. Conversion of these forests into novel formations dominated by alien species would occur in less than 80 years (Dirnböck et al. 2003). It is of primary importance to focus the research on the forest areas to reverse the degradation process. It seems paramount to define realistic goals to ensure the maintenance of the most endangered species as well as implement and document restoration activities.

Beyond the conservation of a single plant or bird species, it is more important to preserve the ecosystems in which those particular species live (Franklin 1993). On Robinson Crusoe Island there could be a relationship among conservation of the montane forest, freshwater production and conservation of marine life near the coast

\footnotetext{
3 P Danton. Personal communication.
}

(Danton and Perrier 2009). In this context, the conservation of the endemic forest of Robinson Crusoe Island would guarantee not only the preservation of the habitat of the most endangered plants and birds, but also the sustainability of fishery which is the most important economical activity of the local community.

\section{CONCLUSIONS}

The forest of Robinson Crusoe Island congregates the most endangered species of endemic vascular plants, and threatened land bird species in an area of less than 900 ha (upper and lower montane forest). These vegetation units can be considered especially attractive for conservation within the whole Juan Fernández Archipelago which is itself a priority area for biodiversity preservation. These woodlands may offer elevated returns for species habitat restoration in the aim of the conservation of most taxa. Scientific attention has not been focused on holistic ecological research including the forest ecology. There is little knowledge about population dynamics of native and exotic plant species or the role of dispersal vectors of invasive species. Either, there are no papers available dealing with restoration including proper monitoring and evaluation. However those matters are of utmost importance in order to protect this endemism hotspot.

\section{ACKNOWLEDGMENTS}

Special thanks go to Josef Greimler (University of Vienna, Austria), Ingo Hahn (University of Münster, Germany), Philippe Danton and Christophe Perriere (Robinsonia Association Grenoble, France) who kindly facilitated their data bases. Without them this review wouldn't have been possible. Thanks to Katja Seis, Dimitriois Samaras, Osvaldo Vidal and Jan Bannister (Freiburg University) who contributed with good tips and comments to previous versions of the manuscript. We are especially grateful to $\mathrm{Mr}$. Iván Leiva, and all the CONAF functionaries on Robinson Crusoe Island and to the residents of Juan Fernández who have always been very supportive. Special thanks to Cecilia Smith-Ramírez for her collaboration and input on the further research for conservation on the Juan Fernández. Thanks to Michael Werner (Western Australia University) for English checking. We appreciate the contribution of two anonymous reviewers. This work was funded by CONICYT Presidente de la República scholarship (Chile), the Georg Ludwig Hartig Stiftung and the Badischen Landesverein für Naturkunde und Naturschutz (Germany).

\section{REFERENCES}

Anderson GJ, G Bernardello, TF Stuessy, DJ Crawford. 2001. Breeding system and pollination of selected plants endemic to Juan Fernandez Islands. American Journal of Botany 88 (2): 220-233. 
Armesto J, R Rozzi, C Smith-Ramirez, M Arroyo.1998. Conservation targets in South American temperate forests. Science 282: 1271-1272.

Bernardello G, G Anderson, P Lopez, M Cleland, T Stuessy, D Crawford. 1999. Reproductive biology of Lactoris fernandeziana (Lactoridaceae). American journal of botany 86(6): 829-840.

Bernardello G, G Anderson, T Stuessy, D Crawford 2001. A survey of floral traits, breeding systems, floral visitors, and pollination systems of the angiosperms of the Juan Fernandez Islands (Chile). The Botanical Review 67: 255-308.

Biodiversa 2009. Taller Internacional: Plan de conservación de la biodiversidad terrestre del Archipiélago Juan Fernández. Valparaíso, 5-6 nov. 77 p.

Biodiversity Hotspots. 2010. Biodiversity hotspot organisation. Consulted on Jun. 17th 2010. Available in: http://www.biodiversityhotspots.org/xp/Hotspots/chilean_forests/pages/ biodiversity.aspx.

Canty A. 2002. Resampling Methods in $\mathrm{R}$ : The boot Package. $R$ News 2 (3): 2-7.

Cronk Q. 1997. Islands: stability, diversity, conservation. Biodiversity and Conservation 6: 477-493.

Castilla J Ed. 1987. Islas Oceánicas Chilenas: Conocimiento Científico y Necesidades de Investigaciones. Santiago, Chile. Ediciones Universidad Católica de Chile, 353p.

Danton, P. 2006. The "myrtisylva” of the Juan Ferndndez Archipelago (Chili), a threatened forest. Acta Botanica Gallica 153: 179-199.

Danton P, Ch Perrier. 2006. Nouveau catalogue de la flore vasculaire de l’archipel Juan Fernández (Chili). Acta Botanica Gallica 153: 399-587.

Danton P, Ch Perrier. 2009. Científicos franceses advierten sobre colapso del ecosistema en Archipiélago Juan Fernández. La Tercera, Abril 11.

de Bello F, S Lavorel, S Díaz, R Harrington, J Cornelissen, M Berg, R Bardgett, P Cipriotti, C Feld, D Hering, P Maritins da Silva, J Sousa, S Potts, L Sandin, D Wardle, P Harrison. 2010. Towards an assessment of multiple ecosystem processes and services via functional traits. Biodiversity and Conservation 19: 2873-2893.

Dirnbök T, J Greimler, P Lopez, T Stuessy. 2003. Predicting future threats to the native vegetation of Robinson Crusoe Island, Juan Fernández archipelago, Chile. Conservation Biology 17: 1650-1659.

Donoso C. 1993. Bosques templados de Chile y Argentina. Variación estructura y dinámica. Santiago, Chile. Editorial Universitaria. 483 p.

Elias R, E Dias. 2009. Gap dynamics and regeneration strategies in Juniperus-Laurus forests of the Azores Islands. Plant Ecology 200(2): 179-189.

Fernández-Palacios J, M Arévalo. 1998. Regeneration strategies of tree species in the laurel forest of Tenerife (The Canary Islands). Plant Ecology 137: 21-29.

Francisco-Ortega J, A Santos-Guerra, S Kim, D Crawford. 2000. Plant genetic diversity in the Canary Islands: a conservation perspective. American Journal of Botany 87: 909.

Franklin J. 1993. Preserving biodiversity: species, ecosystems, or landscapes? Ecological applications 3(2): 202-205.

Greimler J, T Stuessy, U Swenson, C Baeza, O Matthei. 2002a. Plant invasions on an oceanic archipelago. Biological Invasions 4: 73-85.

Greimler J, P Lopez, T Stuessy, T Dirnböck. 2002b. The veg- etation of Robinson Crusoe Island (Isla Masatierra), Juan Fernández Archipelago, Chile. Pacific Science 56: 263284.

Gutierrez A, G Barbosa, D Christie, E Del-Val, H Ewing, C Jones, P Marquet, C Weather, J Armesto. 2008. Regeneration patterns and persistence of the fog-dependent Fray Jorge forest in semiarid Chile during the past two centuries. Global Change Biology 14: 161-176.

Hahn I, U Römer, R Schlatter. 2005. Distribution, habitat use, and abundance patterns of landbird communities on the Juan Fernández Islands, Chile. Ornitología Neotropical 16: 371-385.

Hahn I, U Römer, R Schlatter. 2006. Population numbers and status of land birds of the Juan Fernandez Archipelago, Chile:(Aves: Falconiformes, Columbiformes, Strigiformes, Caprimulgiformes, Passeriformes). Senckenbergiana biologica 86 (1): 109-125.

Hahn I, U Römer, P Vergara, H Walter. 2009. Biogeography, diversity, and conservation of the birds of the Juan Fernández Islands, Chile. Vertebrate Zoology 59:103-114.

Hagen E, P Odum, F Johow, M Wainstein. 2005. Conservación del picaflor de Juan Fernández Sephanoides fernandensis), especie endémica en peligro de extinción. Informe Interno CONAF. American Bird Conservancy. 10 p.

Johow F. 1896. Estudios sobre la flora de las islas de Juan Fernández. Santiago, Chile. Imprenta Cervantes. 288 p.

Kawakami K, I Okochi Eds. 2010. Restoring the Oceanic Island Ecosystem. Impacts and manegament of invasive alien species in the Bonin Islands Tokyo: Springer Japan. http://www.springerlink.com/content/978-4-431-538585/\#section=672321\&page $=1$.

Kier G, H Kreft, T Lee, W Jetz, P Ibisch, C Nowicki, J Mutke, W Barthlott. 2009. A global assessment of endemism and species richness across island and mainland regions. Proceedings of the National Academy of Sciences 106 (23): 9322-9327.

Loope L, D Mueller-Dombois. 1989. Characteristics of invaded islands with special reference to Hawaii. In Drake et al. eds. Biological invasions: a global perspective. Wiley, Chichester: 257-280.

Marín M. 2004. Lista comentada de las aves de Chile. Ediciones Lynx, Barcelona. 141 p.

Marticorena C. 1990. Contribucion a la estadistica de la flora vascular de Chile (Contribution to the statistics of the vascular flora of Chile.). Gayana Botanica 47: 85-113.

Mueller-Dombois D. 1987. Forest dynamics in Hawaii. Trends in Ecology \& Evolution 2: 216-220.

Mueller-Dombois D, FR Fosberg. 1998. Vegetation of the tropical Pacific islands. New York: Springer

Myers N, R Mittermeier, C Mittermeier, G da Fonseca, J Kent. 2000. Biodiversity hotspots for conservation priorities. $\mathrm{Na}$ ture 403: 853-858.

R Development CoreTeam. 2010. R: A Language and Environment for Statistical Computing. R Foundation for Statistical Computing, Vienna, Austria. ISBN3-900051-07-0, URL http://www.R-project.org/.

Rau JR. 2006. Una nueva lista de aves para Chile. El hornero 21: $56-57$.

Ricci M. 2006. Conservation status and ex situ cultivation efforts of endemic flora of the Juan Fernández Archipelago. Biodiversity and conservation 15: 3111-3130.

Rockström J, W Steffen, K Noone, A Persson, F Chapin, E Lam- 
bin, T Lenton, et al. 2009. A safe operating space for humanity. Nature 461(7263): 472-475.

Sitte P, E Weiler,J Kadereit, A Bresinsky, Ch Körner. 2002. Strasburger, Lehrbuch der Botanik für Hochschulen. $35^{\circ}$ ed. Heidelberg, Germany. Spektrum-Akademischer Verlag. 620 p.

Skottsberg C. 1956 (1920-1956). The Natural History of Juan Fernandez and Easter Island. Uppsala, Sweden. Almqvist and Wiksells Boktrickeri AB. 439 p.

Stuessy TF, K Foland, J Sutter, R Sanders, M Silva. 1984. Botanical and Geological Significance of Potassium-Argon Dates from the Juan Fernandez Islands. Science 225: 49-51.

Tomasevic J, C Estades. 2008. Effects of the structure of pine plantations on their "softness" as barriers for ground-dwelling forest birds in south-central Chile. Forest Ecology and Management 255: 810-816.

Vargas R, JG Cuevas,C Le Quesne, A Reif, J Bannister. 2010.
Spatial distribution and regeneration strategies of the main forest species of Robinson Crusoe Island. Revista Chilena Historia Natural 83(3): 349-363.

Veblen T, C Donoso, F Schlegel, B Escobar. 1981. Forest Dynamics in South-Central Chile. Journal of Biogeography 8: 211-247.

Walter H. 2004. The mismeasure of islands: implications for biogeographical theory and the conservation of nature». Journal of Biogeography 31 (2): 177-197.

Wardle D, O Zackrisson. 2005. Effects of species and functional group loss on island ecosystem properties. Nature 435 (7043): 806-810.

Web of Science. 2010. Thomson-Reuters Web of science (formerly ISI Web, Institute for science information). Consulted on Apr. 26th 2010. Available on: http://apps.isiknowledge.com

Recibido: 14.10 .10

Aceptado: 16.05.11 